\title{
Demotic or demonic? Race, class and gender in 'Gypsy' reality TV
}

\section{Annabel Tremlett}

\begin{abstract}
An intriguing shift in the public interest of Roma, Gypsy and Traveller minorities has been the rise of the 'Gypsy' reality TV star in shows across Europe ('Gypsy' is the word most often used in popular media culture). The latest phenomenon to hit the UK has been the Channel 4 series Big Fat Gypsy Weddings (Firecracker Films, Channel 4, 2010-2013), a flamboyant production that has garnered both huge audience shares and fierce criticism, with commentators berating its narrow, sensationalist focus. Drawing on both specialized literature on Roma minorities and current sociological debates on reality TV formats, this article raises questions about how the politics of the 'demotic turn' of such formats (as noted by Turner in 2004) can lean towards the demonic through emphasizing such groups as spectacular, extraordinary and above all, negatively different. Furthermore, this article shows how the series not only reproduces old stereotypes of Gypsies and Travellers as different, ethnicized others but is also heavily embroiled in UK gender and class discourses. Whilst the series claims to be a unique insight into a marginalized community, this close analysis discusses the wider politics within which it is embedded and how such representations can both popularize and undermine marginalized or minority groups.
\end{abstract}

Keywords: class, demotic, demonic, ethnicity, Gypsy, Traveller, minority, ordinary, reality television, representation, Roma, spectacular

\section{Introduction: the rise of the Roma reality media star}

The explosion of popular reality television from the 1990s has been noted for its preoccupation with the interface between ordinary people, media content and celebrity culture. Turner coined the phrase the 'demotic turn' in television broadcasting to describe programming in which the ordinary citizen can get the opportunity to become a celebrity (Turner, 2004: 62). The 'demotic turn' can be seen in a positive light, as working against former elitist notions of celebrity, and therefore 'a reason for optimism, a sign of the democratization of celebrity as the means of production are seized by the ordinary citizen' (Turner, 2006: 156). But as Turner himself points out, the notion that the 'demotic' necessarily stands for 'ordinary', in its meaning of the everyday or 
mundane, is fallacy. Such shows are always produced from an industry that treats cultural identities as commodities, only 'vaguely connected to the social conditions from which they emerge' (Turner, 2006: 163). A growing body of work looks at how these shows are produced in increasingly governed and commercialized societies, and how they frequently use familiar, strong tropes of gender, ethnic and class differences to emphasize a certain vision of how 'new citizens' can emerge from ordinary people (eg Andrejevic, 2004; Biressi and Nunn, 2005; Drew, 2011; Hill, 2008; Ouellette and Hay, 2008; Skeggs et al., 2008; Tyler and Bennett, 2010; Wood and Skeggs, 2011). This literature challenges the notion that these TV programmes are only good for 'mindnumbing, witless vulgarity' (Humphrys, 2004) and instead show the ways such programming engages with current debates around cultural and social values.

This article takes such questioning about the cultural politics of reality television seriously, using UK Channel 4's series Big Fat Gypsy Weddings ${ }^{1}$ as a means to examine reality TV's provocative visualization of ethnic and class relations with regards to 'Gypsies' (the labelling itself is controversial and is discussed in the next section). More specifically, the article contributes to our understanding of the developments in reality TV formats, following the view of other scholars who see the broad label 'reality TV' as useful in thinking through how it 'spectacularizes' the material world (Couldry, 2003; Wood and Skeggs, 2011). It also aims to contribute to research on 'Roma' minorities ('Roma' is the preferred term in many academic publications) by focusing on their representation in popular culture, which has not yet been extensively researched, and to add to the dearth of debates on class and gender in relation to such minorities (Imre and Tremlett, 2011).

My Big Fat Gypsy Wedding was initially a one-off episode in Channel 4's Cutting Edge series broadcast in 2010. Its success catapulted it to a five-episode series, Big Fat Gypsy Weddings, broadcast in 2011 (called here 'Series one'). The audience was regularly over 8 million, reaching the highest ratings for the 9 pm slot since the glory days of Big Brother, Wife Swap and Supernanny in the mid-2000s ${ }^{2}$ (Deans, 2011). This then extended to a few one-off episodes ${ }^{3}$ and another five-part series began in February 2012 (called here 'Series two'). The series has had spin-offs such as When Paddy met Sally (Channel 5, 2011-2012) and Thelma's Gypsy Girls (Channel 4, 2012). Big Fat Gypsy Weddings itself is said to be ending in 2013 after a series of six one-off 'specials'.

The marketing ploy of Big Fat Gypsy Weddings was its claim to unique access to Gypsy/Traveller communities, with Channel 4 pitching the series as fulfilling the channel's remit of 'shining a light on marginal communities' (David Abraham, Channel 4's chief executive, The Independent, 2012). This appears to assert the demotic through broadening the demographics of TV participants. There was no pretence that the 'ordinary' will be a part of this demotic - instead the spotlight was these people's 'extraordinary and fascinating lives' (as described in Channel 4's online DVD promotion ${ }^{4}$ ). Yet whilst Channel 4 claimed uniqueness, in fact, 'Gypsy' presence in reality TV shows is not exclusive to Britain, and has already proved an enduringly popular feature 
in some post-socialist contexts, from Roma popstars having their own reality shows to Roma singers being very prominent in $X$-Factor style TV contests and most recently in North America where Big Fat Gypsy Weddings is now broadcast with a focus on the lives of Gypsies and Travellers in the US (on TLC network from 2012).

The current popularity of Roma minorities in reality TV is said to indicate a shift in their presence in popular culture,

the Roma media star is a new phenomenon, who has transformed the figure of the traditional Roma musical entertainer from tolerated exception into admired, albeit ambiguous, celebrity. (Imre, 2011: 2)

Despite this rise of the 'Roma media star' such representations have not garnered huge academic attention. Romani studies - the academic area - has been largely dismissive of Roma people's involvement in popular culture and provides little precedence for the theoretical challenges involved. Nonetheless, the interest is growing (see, for example, Imre, 2008, 2009; Imre and Tremlett, 2011; Jensen and Ringrose, 2013; Munk, 2007; Tremlett, 2012a, 2013).

This article contributes to this coalescing literature by viewing the way Roma people are involved in popular cultural movements as a valuable resource for further understanding their often complex positioning in social and political life. Such an approach draws on Hall's understanding of the constitutive and formative role that representations take,

how things are represented and the 'machineries' and regimes of representation in a culture do play a constitutive, and not merely a reflexive, afterthe-event, role. This gives questions of culture and ideology, and the scenarios of representations - subjectivity, identity, politics - a formative, not merely an expressive, place in the constitution of social and political life. (Hall, 1996: 443; his emphasis)

Such an approach needs to be carefully framed as it is a relatively new contribution to the discourses surrounding Roma minorities in which contentious debates around labelling, research and stereotyping are very live, as I will now go on to discuss.

\section{The politics of labelling}

The use of the terms 'Gypsy' or 'Traveller' are often highly emotive and controversial as well as ambiguous in the possibility of being prejudicial - they have been used as racist terms (along with extremely offensive versions such as 'gypo' or 'pikey') and their usage is still heavily debated (Bhopal and Myers, 2008). In European institutional discourses and frequently in academic literature the term 'Roma' is used as an umbrella term for all these groups, although 
not without controversy as it is said to be an ethnonym for only certain groups while others reject it, making collective representation a challenge (McGarry, 2010).

The use of 'Gypsy' and 'Traveller' in the UK is no less controversial. This was particularly crystallised in the wave of criticism from the promotion of the 2012 series in which huge advertising billboards spelled out the slogan 'Bigger, Fatter, Gypsier', and some billboards found themselves graffitied with the addendum 'MORE RACIST'. Channel 4's use of this made-up word 'Gypsier' was picked up by commentators as provocative in its intentional play with the ambiguity of offensiveness - for example, a spokesperson from the London Gypsy and Traveller Unit said 'the fact that the word "gypsier" is used, what is this all about? To me it sounds [as though] the word "gypsier" is used in a pejorative sense' (Brown, 2012; see also Cawley, 2012). The Advertising Standards Authority (ASA) received over 370 complaints in March 2012, but it was only after legal representatives from the Irish Traveller Movement in Britain appealed the decision that the ASA agree to conduct a formal investigation into the Channel 4 campaign and banned two of the adverts from ever being published again (see ASA, 2012). Travellers' Times journalist Jake Bowers, along with others, criticized the series for perpetuating old stereotypes and encouraging new racism, for example as purporting to be all about 'Gypsies' when in fact mostly Irish Travellers were shown, saying 'blurring the difference between Irish Travellers and Romany Gypsies is about as useful as confusing Dublin with Delhi' (Bowers, n.d.; see also McKenzie, 2012).

This article does not attempt to address this issue by explaining the different cultures and histories (mis)-represented in Big Fat Gypsy Weddings. Rather it is focused on the techniques and cultural politics of the representations of 'Gypsy' and 'Traveller' communities as so-labelled in Channel 4's Big Fat Gypsy Weddings. In this article I use such labels as broad categories that were used in Big Fat Gypsy Weddings with the recognition that they are inadequate for dealing with the variety of ethnic, cultural and social backgrounds of the people depicted in the programmes. In terms of this article, I am not looking at how ethnicity or group identity is experienced or expressed by people themselves, but how it is represented, seeing popular culture as a space in which cultural politics of difference are played out, a display of 'the struggles around difference, of the production of new identities, of the appearance of new subjects on the political and cultural stage' (Hall, 1993: 105). This is not to deny the damaging effects of Big Fat Gypsy Weddings, but to explore the ' "machineries" and regimes of representation' (Hall, 1996: 443).

The fact I have had to emphasize a focus on representations signals a major difficulty in writing about such misrepresented and at times marginalized communities. Big Fat Gypsy Weddings is highly criticized by many Gypsy and Traveller people and groups as being a caricature of their communities. Through focusing on such a programme the aim of this article is not to further misrepresent such communities, but rather to investigate the mechanics of such representations, reminding ourselves that reality television is embedded 
in 'thorny debates about representing ordinary people'; 'politically loaded' and 'no less complex and conflicted as social texts' (Biressi and Nunn, 2005: 2).

\section{The theoretical challenge: representations of race}

The theoretical challenge is how to understand the Roma reality media star as a rising phenomenon in the global media formats of reality TV whilst recognizing the particular regional locations and histories that home audiences watch such shows within. Such a focus requires a theoretical framework that is aware of the potency of harmful racialized stereotypes, yet can also cope with understanding the specifics of national histories and approaches to notions of identities - which become inflected or reproduced through reality TV (Tremlett, 2012a). In order to tackle such a challenge, this analysis of Big Fat Gypsy Weddings necessarily draws on both specialized literature on Roma minorities and essentialized identities, along with current sociological debates on reality TV formats. Here I briefly outline this literature and the main issues.

Romani studies - the academic area devoted to research on Roma minorities - has traditionally focused on the ethnic/group characteristics, or identifications that make people 'Roma' or 'Gypsy' and pays less attention to their similarities to other groups or connections to wider discourses, for example around gender or class. There has also been a lack of theoretical discussion in Romani studies on both theoretical approaches to terms such as 'ethnicity', 'race', and 'class' (Tremlett and McGarry, 2013). In addition, Romani studies has either ignored or been dismissive of TV engagement leading to a rather 'anachronistic and idealised image of the Gypsy as a figure unaffected by contemporary popular culture' (Imre and Tremlett, 2011: 92). All these factors link to the criticism that Romani studies remains 'isolated' from other academic subjects, running the risk of reproducing essentialized representations of 'the Gypsies' (for further discussions see Durst, 2011; Lemon, 2000; Theodosiou, 2011; Tremlett, 2009, 2012b; Willems, 1997). This article contributes to Romani studies by considering how 'race' and 'class' are represented by such shows, and explores what its popularity begins to tell us about the shifting dynamics of reality TV and wider representations of Gypsy and Traveller communities.

The article also contributes to literature on reality TV and race/class. Literature on representations of race in British cultural studies (begun by Stuart Hall) is combined with a sensitivity to the particular formulations of 'Gypsy' embedded in European histories (Bhopal and Myers, Imre, Mayall, Willems). At the same time, class and gender discourses are also very relevant. Whilst the general consensus is that the series is all about 'the Gypsies' and therefore about their group (ethnic) identity, the added infusion of class discourses to the series spills out very obviously in the media commentaries:

We've become trailer trash versions of the Flintstones there for your TV entertainment. (Bowers, n.d.) 
A couple promise to chav and to hold - at a gypsy wedding where the bride wears a dress resembling a giant blancmange. (The Sun, 2011)

My Big Fat Gypsy Wedding claims to celebrate a unique traditional culture. Pull the other one, it makes Jordan look classy! (Moir, 2011)

And we are encouraged to laugh at and judge the participants. We're given close-ups of their chubby bodies spilling out of skimpy outfits. (Hyland, 2012)

These quotes strongly point to class-based stereotypes - 'trailer trash' and 'chav's are demeaning terms for white working-class people; 'dress resembling a giant blancmange' and 'chubby bodies spilling out of skimpy outfits' are classic working-class female stereotypes (inappropriate bodies, ridiculous dress); whilst the reference to glamour model, reality TV star and 'celebrity chav' Jordan (also known as Katie Price) situates the series' participants firmly in derogatory class discourses (Jones, 2011; Tyler and Bennett, 2010).

UK-based scholars of reality TV have argued that classed identities are at the forefront of British reality shows (eg Skeggs, Wood, Tyler, Tyler and Bennett). Skeggs et al. blend a Foucauldian emphasis on governmentality with Bourdieu's notions of the habitus and forms of capital to show how predominantly working-class groups are devalued and subsequently reinvented to suit middle-class 'taste' (see Skeggs et al., 2008). This article takes these class discourses seriously, following Skeggs and Wood in their argument that class is no 'zombie category' (as described by Beck and Beck-Gernsheim, 2002) but is actually becoming even more pertinent in the current socio-economic climate (Skeggs and Wood, 2011). This article bases its theoretical underpinnings on the following Bourdieu-inspired sociological analysis of class:

If class consciousness is not what it once was, class inequality is certainly increasing [...] New capitalist modes of production only reorganise those that cannot mobilise themselves around the shifting job market, leaving many - the so-called underclass 'chavs' in the UK, or the 'white trash' and racialised 'poor' of the US - related to the mode of production by their very alienation from it, discarded (literally and metaphorically) as the 'waste' of the 'system'. (Skeggs and Wood, 2011:4)

Drawing on all this literature, I first focus on the essentialized framing and narration adopted by Big Fat Gypsy Weddings that points to wider discourses on racialized representations, before looking at the ways the series embroils itself in UK discourses on gender and class.

\section{Racialized framing and narration}

The different episodes of Big Fat Gypsy Weddings are held together through strong and prominent framing techniques: first, through a repetitive opening 
that is strikingly similar for each episode; and secondly through the narration. First, the openings to each episode are near-identical and thus frame the series in a certain manner: 'For hundreds of years, the Traveller way of life was one of ancient traditions and simple tastes', begins the voiceover, accompanied by images of a traditional horse-drawn wagon, horses being bathed in a river, older women with headscarves drinking tea around a campfire. The background music is gentle, slow and evocative. This is a notion of an 'ideal' or 'true Gypsy' (in Hall's terms, 'the innocent notion of the essential black subject', Hall, 1996: 443) that has been an influence on the representations of Gypsies since it was constructed in late nineteenth-century and early twentieth-century romantic art and literature when Gypsy folklore was popularized. These representations had more to do with the writers' desires and political and artistic climate at the time, and less to do with an actual way of life for a defined group of people (Willems, 1997). In the opening scenes of Big Fat Gypsy Weddings we are thus being shown a certain representation of 'groupness' clearly identifiable with 'Gypsy', as 'the romantic, free-living and free-loving Romanies [...] leading a rich and exciting life' (Mayall, 2004: 2).

But this romantic image soon gets turned on its head, 'then their world collided with the twenty-first century', continues the voiceover. Suddenly the music breaks into a faster, whirling dance-like melody: shots of skimpily clad young girls writhe their hips under disco lights and young women in enormous, white and sparkling or brightly coloured dresses are shown teetering down driveways and being crammed into limos and carriages. The flamboyance of attire and dance suggests Bakhtin's (1941) notion of the carnivalesque as subversion and liberation from the constraints imposed by the majority, another stereotypical image of Gypsies and Travellers as 'epic figures transgressing the rules of society' (Martin, 2002: 723).

But at this point we move away from purely 'Gypsy' stereotypes. The dance moves of the young girls are not reminiscent of traditional Gypsy-style dancing, but more akin to the belly-dance/hip-hop moves of American pop stars Shakira and Beyonce (in a later episode young girls confirm these pop stars are the ones they mimic). A brief shot of teenage girls in casual clothing strutting down a sunny street shows one turning briefly to the camera shouting 'you want some beef? I'll give you some beef!' The use of the term 'beef' (meaning 'aggression') locates the girls in UK urban youth cultures that draw on American rap influences (Briggs, 2010). From a gentle, traditional world depicted by the horse and cart and older adults talking and drinking tea, to a wild, brash, hyped-up sexualized youth culture, Gypsies are likened to common stereotypes of UK urban youth, and as a consequence appear younger, louder and tackier than their traditional roots. They are still being shown as a certain 'group', but one linked not only to essentialized traditional representations of Gypsies but also to wider representations of urban youth that points to wider discourses on 'otherness'.

Alongside this repetitive opening to each episode, the second framing technique is narration. For the narration there is both the sonorous tones of a 
faceless voiceover and then very personable narratives from people in the know', and here I focus on the prominence of Thelma Madine, a dressmaker who is responsible for many of the dresses shown in the series and who has now become a TV personality in her own right with her own show Thelma's Gypsy Girls (2012, Channel 4). Thelma is often filmed leaning over the counter or pinning dresses, confiding in the camera like a warm, gossipy aunt, adding her knowledge in a role akin to the 'privileged' or 'knowing' stranger so familiar in ethnographic writing (Ahmed, 2000). As Thelma writes in her book, 'since I was welcomed into the traveller community many years ago, I have been lucky enough to get a rare insight into what really goes on in their world' (Madine, 2012: xii). From this position she gives opinions on Gypsy and Traveller lives that are then inserted to explain the given scene. She is thus used as a thread that links disparate lives to an overarching generic Gypsy theme that confirms the statements of the voiceover. For example, in the episode 'Born to Wed' the voiceover says 'with unprecedented access to the UK's most secretive communities, this series will take you to the very heart of Gypsy life'. The sentence breaks off mid-way to allow an insert of Thelma saying, 'they don't like anybody knowing anything about them at all - they even have their own language'. The positioning of 'they' complements the voiceover's predication of a generic 'Gypsy life' as well as perpetuating an old stereotype of Gypsies as secretive and clandestine.

This mode of editing between voiceover and narrator is common throughout Big Fat Gypsy Weddings, and points to the techniques at the heart of the criticism that the series caricatured all Gypsy and Traveller groups into one 'Gypsy' stereotype. In the series the voiceover actually does introduce a particular scene by attaching a specific ethnonym to the people depicted, for example 'English Gypsy', but then slips more generic terms, such as 'Gypsy' or 'Traveller', to describe culture or tradition. For example: one prominent character, Paddy Doherty, is introduced as 'Irish Traveller Paddy'. We then see him filmed in a furniture shop having bargained a price, but reluctant to tell the cameras what he finally paid. Suddenly, 'Irish' is dropped as the narrator says 'like all Traveller men they keep money secret' (Series one, episode 4, 'Boys will be boys'). Another character, Swanley, is introduced as 'an English Gypsy'. However, when describing children going to Swanley's wedding the voiceover says 'as is the tradition in Traveller families the children make their own way to church complete with bottle of fake champagne' (Series one, episode 1, 'Born to wed'). Thus Swanley as 'an English Gypsy' becomes conflated with a construction of a wider notion of 'Traveller' traditions. Similarly, whilst another young woman, Lizzie, is said to be an 'Irish Traveller girl', after showing her wedding the narrator says 'Now a Gypsy housewife, Lizzie has her own caravan to look after' (Series one episode 3 'Desperate housewives', which takes its name from the US series Desperate Housewives). Interchanging terms, such as from 'English Gypsy' to 'Traveller' or from 'Irish Traveller' to just 'Traveller' or 'Gypsy', seems to signal a slippage into generic talk about 'the Gypsies' or 'the Travellers' without acknowledging particular identities, 
culture or histories of the different groups, something that is very common in discourses about such groups and contributes to essentializing core traits (see Tremlett, 2009).

Here we can also see power in the use of indexical markers ${ }^{6}$ with words such as 'all', 'the' and 'a' pointing to a generic discourse which firmly points to some kind of template of 'Traveller' or 'Gypsy':

- 'like all Traveller men';

- 'as is the tradition of Traveller families' and

- 'now $a$ Gypsy housewife'

The template these refer to is easily recognizable as combining old Gypsy stereotypes with broader racialized stereotypes, what could be termed a 'racialized regime of representation' (Hall, 1997: 269) as is summarized in Table 1.

Using these representations, the voiceover points the audience to a familiar framework of Gypsy and wider racialized stereotypes in which the fundamental characteristics of 'Gypsies and Travellers' are already apparent. The opening to each episode and the editing and language of the voiceover and narrator are examples of the art of racialized framing employed by Big Fat Gypsy Weddings. 'The final element to be added to the racially constructed Gypsy', writes Mayall, 'is the view that they have always and everywhere remained a primitive and savage people' (Mayall, 2004: 139). The material is selected and rearranged so that in the end we have a particular world described in stereotypical, racialized terms.

\section{Gender and class formulations in 'the dress'}

As we have just seen, the framing and narration in Big Fat Gypsy Weddings works to summarize the Gypsy or Traveller culture to a certain template. This gives the impression that everything we see is somehow connected to a broader, essentialized notion of 'Gypsy' that also links to wider racialized representations of minorities and loses any specific cultural or historic context, reminding us of Turner's criticism that the 'demotic turn' in reality TV glosses over social conditions and ignores potential for social and cultural change (Turner, 2006: 163). The recurrent theme throughout the series is that the dress epitomizes what it means to be 'Gypsy'. Even in their defence of the series for the Advertising Standards Authority Channel 4 highlighted the 'Gypsiness' of big dresses, calling it 'the wedding dress phenomena' among 'Gypsy and Traveller brides who tried to out-do each other with extravagant wedding dresses and wedding receptions' (ASA, 2012). In this section I look at how the main visual focus of the series - the enormous dresses - continues the essentialized narrative of who 'the Gypsies' are, but this time through gender and class discourses.

One episode could not be more direct in referencing Gypsies as an exoticized 'other' through the dresses: 'I'm a pineapple and she's a palm tree' declares Irish 
Table 1 Racialized stereotypes in Big Fat Gypsy Weddings

\begin{tabular}{|c|c|c|}
\hline Voiceover phrase & Gypsy stereotype & $\begin{array}{c}\text { Broader racialized } \\
\text { stereotype }\end{array}$ \\
\hline $\begin{array}{l}\text { 1. 'Like all Traveller } \\
\text { men they keep } \\
\text { money secret' }\end{array}$ & $\begin{array}{l}\text { They are secretive and no } \\
\text { one knows how they get } \\
\text { their money: this is a } \\
\text { nineteenth-century } \\
\text { stereotype of 'the Gypsy } \\
\text { as vagabond' with 'exotic, } \\
\text { unfamiliar ambience' and } \\
\text { 'secret language' (Willems, } \\
\text { 1997: 156), a representation } \\
\text { that can still be seen today } \\
\text { (Mondestino, 2001). }\end{array}$ & $\begin{array}{l}\text { Minorities as secretive and } \\
\text { impenetrable to outsiders is } \\
\text { a common representation, } \\
\text { particularly for immigrants } \\
\text { (Berglund, 2005; van Dijk, } \\
\text { 2000). }\end{array}$ \\
\hline $\begin{array}{l}\text { 2. 'As is the tradition } \\
\text { in Traveller } \\
\text { families the } \\
\text { children make } \\
\text { their own way to } \\
\text { church complete } \\
\text { with bottle of } \\
\text { fake champagne' }\end{array}$ & $\begin{array}{l}\text { They are irresponsible with } \\
\text { their children and have } \\
\text { extravagant parties: the } \\
\text { 'drawn-out, fully exoticized } \\
\text { Gypsy celebration' is a } \\
\text { popular media and film } \\
\text { representation (Imre, } \\
\text { 2005: 91). }\end{array}$ & $\begin{array}{l}\text { See discourses around 'bling' } \\
\text { and the 'specific stance } \\
\text { on black conspicuous } \\
\text { consumption' (Mukherjee, } \\
\text { 2006). }\end{array}$ \\
\hline $\begin{array}{l}\text { 3. 'Now a Gypsy } \\
\text { housewife, Lizzie } \\
\text { has her own } \\
\text { caravan to look } \\
\text { after' }\end{array}$ & $\begin{array}{l}\text { Traditional gender roles are } \\
\text { kept which are oppressive } \\
\text { to women. Evidence of the } \\
\text { 'true, racially pure Gypsy' } \\
\text { was seen in their adherence } \\
\text { to strict gender roles in } \\
\text { marriage - savage men } \\
\text { and 'kept' women (Clark, } \\
\text { 2004: 134). }\end{array}$ & $\begin{array}{l}\text { Black stereotypes have } \\
\text { focused on gender divisions } \\
\text { with men as aggressive, } \\
\text { women as oppressed (Blair, } \\
\text { 2001: 36); whilst the 'brown' } \\
\text { women is seen in need of } \\
\text { rescuing, 'white men saving } \\
\text { brown women from brown } \\
\text { men' (Spivak, 1988: 297). }\end{array}$ \\
\hline
\end{tabular}

Traveller Dolores (Series two, episode 1), barely standing upright alongside her best friend in incredible outfits of garish green, yellow, blue and glitter, complete with tropical headpieces. Their dresses are in stark contrast to the gloomy darkness of the terraced streets of Rathkeale, County Limerick, as the cameras follow their cheerful attempts to squash these outfits into an enormous white limousine in the pouring rain. The dressing up in tropical fruit and tree outfits is an open invitation to see the young women as exotic others - indeed, throughout the series the big, extravagant dresses in particular are seen as key to understanding the 'secretive' world of the Gypsies. ${ }^{7}$ However, these dresses are hardly the exotic in the sense of traditional Gypsy romantic stereotypes of fortune-tellers, musicians or handicraft experts (Okely, 1996: 46) but in fact, point more to class-based stereotypes. 
The reason Dolores is dressed in such spectacular clothing is because she is attending her hen party, a celebration in which the bride-to-be gathers together all her female friends for a final send-off. Notably gaining popularity in the UK since the mid-2000s, hen parties have become increasingly entrenched in class discourse, with Skeggs noting how 'the tastelessness of the hen display' has become a product of the classificatory history of workingclass women, 'read as repositories of negative value, bad taste and culture (as bad-objects rather than subjects)' (Skeggs, 2004: 167). Once again, the representations in Big Fat Gypsy Weddings move beyond basing themselves in solely 'Gypsy' stereotypes to wider notions of 'otherness', this time class.

Throughout the series, the big, extravagant dresses in particular are said to be key to understanding the 'secretive' world of the Gypsies, yet also linked to UK-based class and gender discourses.

The modern inclination towards big, sparkly dresses has been noted elsewhere. Orenstein calls it a 'princess obsession' driven by Disney's marketing in the US in which young girls seek out sparkle, tutus, fairy wings and the colour pink 'like heat-seeking missiles' (2011:35). In the UK, the princess obsession, whilst obviously influenced by the American market place, can also be seen as influenced by interest in the British monarchy. The 2011 marriage of Prince William to Catherine Middleton created a huge amount of speculation about what 'Kate's dress' would look like, with constant reference to the wedding dress of her groom's late mother, Lady Diana. As a young bride, Diana Spencer stepped out of her horse-drawn carriage with the BBC commentary focused solely on capturing a description of the dress which reveals how the 'princess culture' was already embedded in the UK imagination,

... and if you asked a little girl to draw a princess I think she'd draw a dress just like that. A tiny bodice, a tiny waist and a great big skirt. (BBC commentary, $1981^{8}$ )

The dresses and celebrations shown in Big Fat Gypsy Weddings follow this princess trend with many close-ups of young women being fitted with similarly styled dresses with tiny bodices and huge layers of petticoats and skirts.

But as Skeggs points out, the divide between what counts as 'taste' and 'tastelessness' (coming from Bourdieu's phrase 'taste classifies, and it classifies the classifier' Bourdieu, 1986: 56) is drawn up around class divisions, 'in order that only some people can be seen to comfortably make use of them' (Skeggs, 2004: 108). Thus, whilst Diana Spencer's huge wedding dress was applauded as regal and tasteful, when people from working-class backgrounds take up such trends it is seen as tacky or tasteless. When UK's glamour model 'Jordan', for example, married Australian pop star Peter Andre in 2004, her wedding was complete with a huge puff-ball princess-style dress and horse drawn pumpkin carriage. Yet Jordan, from a working-class background, was not likened to a royal princess, but rather called a 'celebrity chav' (Hayward and Yar, 2006). Images of the couples in Big Fat Gypsy Weddings closely mirror such 'celebrity 
chav' wedding couples. In fact, one couple actually hired the exact same pumpkin carriage as Jordan's. This is a princess culture that, when represented by the upper or middle classes is something regal and tasteful, but when represented by the working classes, is seen as tacky, over-the-top and extravagant, and when represented by Gypsies and Travellers is represented as evidence of their essentialised otherness.

\section{Alternative representations of gender}

So far in this article I have examined how Gypsies and Travellers were constructed in Big Fat Gypsy Weddings as racialized others through two main techniques of framing and narration. I then moved on to show how the series is also embroiled in British gender and class discourses that serve to position Gypsy and Traveller women in similar, negative terms as white working-class women. This has highlighted a key intersection between race, gender and class that is used in a way to highlight the 'otherness' of Gypsies and Travellers as well as tapping into popular trends of consumerism and materialism. This key intersection needs further investigation with regards to wider representations of Roma minorities. However, to leave the analysis here would not acknowledge the moments in Big Fat Gypsy Weddings when serious topics such as female oppression and discrimination are tackled. Here I want to consider a few examples to examine how the series chose to show such topics.

A theme running through the series is the notion of strict gender divisions with men drinking and fighting; women as made-up, but oppressed housewives. Jensen and Ringrose note how such a representation creates a 'powerful affective dynamic' that is suggestive of the problem being with the Gypsies themselves, 'a way to justify condemnation and even vitriolic hatred of the Gypsy and Traveller Others as sexually regressive and backwards' (2013: 11; their emphasis). For example, in the episode 'Desperate Housewives' (Series one episode 3 ) the opening shots of glamorous dresses are juxtaposed with images of women cleaning caravans, 'behind the perma-tan and jewels there is a very different story' says the voiceover. 'Traveller women are second hand citizens' confirms the dressmaker Thelma Madine (using the complementary framing technique noted earlier), 'they have a lot to say, but when it comes down to the nitty gritty they're kept in their place'. Traveller women are shown as hyper-sexualized and socially noisy, but with no real political voice.

Nevertheless, and perhaps surprisingly, there are scenes in the series that do not corroborate the view of women as 'sexually regressive and backwards'. For example, the episode 'No Place Like Home' (Series one episode 2) begins with images of violent arrests at a protest by a camp, and then of a crane demolishing a static caravan. The episode shows two evictions: from Hovefield and Dale Farm Traveller sites, both in Essex. Female Travellers are depicted at the forefront of the protests - Catherine from Hovefield says that she 'tried to fight the council everywhere and anywhere but I can't. I can't do it anymore 
it's too stressful' whilst Margaret (a grandmother) sits in front of her static chalet saying that 'the bailiffs will have a fight on their hands'. These women are determined and forthright in their attitudes amidst a seemingly hopeless situation. However, the time given to these women in the episode is very short: out of the 48-minute programme only 9 minutes are devoted to showing the evictions. The other 39 minutes of the episode are focused on dresses and parties with close-ups of young girls either dancing in skimpy outfits or being subsumed by enormous dresses. The insights into these women's worlds are limited and we gain only glimpses into the political territory they are attempting to navigate.

Aside from Catherine from Hovefield and Margaret from Dale Farm taking part in political activities, there are other women who also do not fit the predominant image of women as the pathologized oppressed. There is Noreen (Series one episode 3) who is not married and earns her living working in a cake shop. For her birthday celebration Noreen invites male and female friends to go paint-balling - thus Noreen does not fit into the supposedly 'typical' Traveller female stereotype. Equally, a mother of one of the brides in the episode 'Bride and Prejudice' (Series 1 Episode 5) talks about raising her children by herself and speaks of how she stood up to the violent behaviour of her husband, whilst Violet-Ann (Series 1 Episode 4) and Joan (stand alone episode 2010) both talk of holding down permanent jobs before getting married.

In Bourdieu's terms, these women, born into the structures of inequality, have only a certain amount of capital at their disposal in order to move through social space (Bourdieu, 1986). Whilst the examples described above do not serve to fully relinquish the principal representation of Gypsy and Traveller women as oppressed, they do question the prominent framing of women just as victims, constantly trapped in an oppressive home environment. However, the audience is never invited to question the prominent framing as these women are described in the series by the voiceover or dressmaker as 'unusual'. 'The Gypsy woman', by definition excluded from 'normal' activities such as employment and politics, are here 'performing the role of the model exception that confirms the rule about the bad minority' (Imre, 2009: 124). Had the series given more time to the footage of instances of independence and political activism, or explored the variety of groups and identities shown and less time to dresses and celebrations, it could have afforded a deeper insight into how these women negotiated the structures of inequality and differential amounts of capital afforded to their positions.

\section{Conclusion: demotic or demonic?}

Reality TV found its niche through offering the opportunity for ordinary people to appear in the media. Turner has called this the 'demotic turn', 'a celebration of the performing self [...] in which the participation of ordinary people tends to involve some kind of reference to or representation of their 
everyday lives' (Turner, 2010: 171). In this article I have shown how Big Fat Gypsy Weddings loses any pretence that its participants are ordinary and instead focuses on the spectacular through using essentialized tropes of Gypsies as different and extraordinary/demonic. The way the series achieves this is through repetitive use of certain framing, narration and visual displays that blends an essentialized template of what a 'Gypsy' is with familiar (to the UK audience) representations of racialized identities, gender and class differences.

Relating back to the wider literature, this article contributes in two ways: first, it contributes to the scarcity of literature on Roma minorities and popular culture, seeing popular culture as a dynamic and important lens to understand the wider social and cultural positionings of such minorities. Second, it adds to discussions on reality TV by substantiating criticisms of the 'demotic turn' which frequently loses the chance to truly democratize television by glossing over insights or debates on social conditions, inequality and social justice. Skeggs et al. take a Bourdieu-feminist line in which representations of dysfunctional gender are seen to coincide with dysfunctional consumption and classed 'trashiness'. Big Fat Gypsy Weddings' portrayal of Gypsy 'excess' is consistent with Skeggs et al.'s work on working-class women and provides further evidence of how reality TV can use a non-mainstream group to create further marginalizing, demonic discourses.

However, I do not want to end this article by dismissing Big Fat Gypsy Weddings as only a 'freak show' (Sutcliffe, 2011) or 'Gypsy circus' (Kürti, 2008: 17). This is the view taken by many critics - that such programmes simply give the audience something to despise:

What will keep quite a lot of viewers coming back is the spectacle of style so flamboyantly devoid of taste that virtually anyone watching will feel like Coco Chanel by contrast [...] There is a freak-show element to the series that no amount of covering talk about proud communities and ancient traditions will cover up. (Sutcliffe, 2011)

Critics such as Sutcliffe see the series as an uncomfortable indulgence in gleeful voyeurism, what Billig might call the 'pleasures of hatred' (2001). Indeed, outlandish prejudicial comments jump out when scrolling down Twitter feeds and online comments/blogs can shockingly show how vitriolic and racist reactions have been (see Jensen and Ringrose, 2013). Nevertheless, the danger is that we can too easily explain away the high viewing figures of Big Fat Gypsy Weddings as down to the audience taking macabre delight in watching something they deride.

The popularity of such programmes could signify a potential shift away from the pedagogic (didactic) notions of 'betterment' displayed in the many makeover/lifestyle reality shows. As Ouellette and Hay (2008) point out, in any given week we can learn how to improve ourselves through a vast array of reality programmes, from work life in The Apprentice to romance in Snog 
Marry Avoid?, fashion advice in What Not to Wear, cooking and household management in Masterchef and Money Saving Expert. The sudden and sustained popularity of Big Fat Gypsy Weddings may actually indicate a thirst in the audience for something different, maybe a different display of 'personhood', as Skeggs writes,

not all people want to engage in, or can access, the value practices necessary for becoming a capital loaded fetish form of value. They may have better things to do with their time and energy. (Skeggs, 2011: 508)

Perhaps audiences are sick and tired of the 'inner-facing, pseudo-religious, bourgeois self' that haunts the strident moral agenda of self-improvement or observational reality TV (Skeggs, 2011: 497), and shows like Big Fat Gypsy Weddings may indicate a release from the structures of imposed neo-liberal ideas of the productive, constructed, self-accrued singular 'self'. This deserves more research, and the next step is understanding audience responses through close-up empirical research (including audiences from minority communities) that would help our understanding of such minorities as not just performers but also as members of the audience (Tremlett, 2012a). Whilst Big Fat Gypsy Weddings can be criticized for its extreme focus on spectacular events, narrow framing of racialized stereotypes, and failure to use its spotlight to tackle social justice problems of discrimination and inequalities faced by Gypsy and Traveller people, its popularity may prove a shift in what we see as the 'constitutive limit to proper personhood' (Skeggs, 2011: 509).

\section{Acknowledgements}

I am grateful for encouraging comments on early and later drafts from my peers at 'The Write Club' group, and also from Dr Stephen Harper and Dr Justin Smith, all at the University of Portsmouth. I also am indebted to the discussion after my presentation of this paper at the Research Workshop in Language at Literacy (RWLL) at King's College London (22 January 2013) and to the two anonymous reviewers for their insightful remarks.

\section{Notes}

1 Big Fat Gypsy Weddings takes its title from the Hollywood blockbuster My Big Fat Greek Wedding (2002). Rather than raising any ethnic controversies, My Big Fat Greek Wedding's popularity was said to come from its safe adherence to a heart-warming version of the American dream (Engstrom and Semic, 2003; Perren, 2004). Whilst a film focusing on American Greeks confirms ideas around what a national family should look like, a focus on UK Gypsies and Travellers produces controversy and media uproar. 
2 See statistics from BARB (Broadcasters Audience Research Board], available at: www.barb.co.uk/report/weeklyTopProgrammesOverview (accessed 15 March 2011).

3 My Big Fat Royal Wedding was broadcast on the eve of the British Royal Wedding of Prince William and Catherine Middleton in April 2011, whilst My Big Fat Gypsy Christmas was broadcast December 2011.

4 See Channel 4's online programme information, available at: www.channel4.com/programmes/ big-fat-gypsy-weddings/articles/dvd (accessed 10 June 2012).

5 The word 'chav' is often said to be an acronym standing for 'Council Housed And Violent'. However, it is also noted as coming from a Gypsy language as 'chavvie' is used in British Romany language to mean 'child', whilst in Hungarian 'csávó' is said to derive from a Romani dialect meaning 'bloke' or 'guy'.

6 This takes the view of language as an ideological object, 'an object invested with social and cultural interests, not just a vehicle for (denotational, neutral) meaning' (Blommaert et al., 2005: 199).

7 Channel 4 describes the series as a 'revealing documentary series that offers a window into the secretive, extravagant and surprising world of gypsies and travellers in Britain today'. This text is set as beside a picture of a bride in a huge wedding dress. Available at: www.channel4.com/ programmes/big-fat-gypsy-weddings (accessed 14 January 2013).

8 See coverage on BBC website. Available at: www.bbc.co.uk/programmes/p00fj1gx (accessed 25 March 2012).

\section{References}

Ahmed, S., (2000), Strange Encounters: Embodied Others in Post-Colonialityh, London: Routledge.

Andrejevic, M., (2004), Reality TV: The Work of Being Watched, Lanham, MD: Rowman \& Littlefield.

ASA, (2012), 'ASA Adjudication on Channel Four Television Corporation', 3 October, available at: www.asa.org.uk/Rulings/Adjudications/2012/10/Channel-Four-Television-Corporation/SHP _ADJ_197451.aspx (accessed 12 January 2013).

Bakhtin, M., (1941), Rabelais and his World, Bloomington, IN: Indiana University Press.

Beck, U. and Beck-Gernsheim, E., (2002), Individualization, London: Sage.

Berglund, B., (2005), 'Chinatown's tourist terrain: representation and racialization in nineteenthcentury San Francisco’, American Studies, 46 (2): 5-36.

Bhopal, K. and Myers, M., (2008), Insiders, Outsiders and Others: Gypsies and Identity, Hatfield: University of Hertfordshire Press.

Billig, M., (2001), 'Humour and hatred: the racist jokes of the Ku Klux Klan', Discourse and Society, 12 (3): 267-289.

Biressi, A. and Nunn, H., (2005), Reality TV: Realism and Revelation, London: Wallflower Press.

Blair, M., (2001), 'The education of black children: why do some schools do better than others?', in Richard Majors (ed.), Educating our Black Children: New Directions and Radical Approaches, 28-45, London: Routledge.

Blommaert, J., Collins, J. and Slembrouck, S., (2005), 'Spaces of multilingualism', Language and Communication, 25: 197-216.

Bourdieu, P., (1986), Distinction: A Social Critique of the Judgement of Taste, London: Routledge \& Kegan Paul.

Bowers, J., (n.d.), 'Our cheap dirty traveller embarrassment', Travellers' Times online, available at: www.travellerstimes.org.uk/blog.aspx? $\mathrm{n}=\mathrm{c} 6 \mathrm{e} 13428-2329-462 \mathrm{~b}-\mathrm{a} 0 \mathrm{f} 8-\mathrm{f} 6 \mathrm{ccab} 22 \mathrm{ced} 7 \& \mathrm{c}=\mathrm{f} 1 \mathrm{~b} 1 \mathrm{c} 82 \mathrm{c}-$ 0f3c-4edf-98cd-502ea80ed8fa (accessed 15 October 2013).

Briggs, D., (2010), 'True stories from bare times on road: developing empowerment, identity and social capital among urban minority ethnic young people in London, UK', Ethnic and Racial Studies, 33 (5): 851-871. 
Brown, J., (2012), Today programme, BBC Radio 4, 17 February, available at: http:// news.bbc.co.uk/today/hi/today/newsid_9697000/9697089.stm (accessed 15 March 2012).

Cawley, C., (2012), 'My Big Fat Gypsy Wedding exploits out community for cheap laughs', Guardian online, 14 February available at: www.guardian.co.uk/commentisfree/2012/feb/14/ big-fat-gypsy-wedding-exploits-community (accessed 11 July 2012).

Clark, C., (2004), 'Severity has often enraged but never subdued a gipsy: the history and making of European Romani stereotypes', in Nicholas Saul and Susan Tebbutt (eds), The Role of the Romanies, 226-246, Liverpool: Liverpool University Press.

Couldry, N., (2003), 'Media, symbolic power and the limits of Bourdieu's field theory', in Media@ lse Electronic Working Papers series, available at: www2.lse.ac.uk/media@lse/research/ mediaWorkingPapers/archive/ewpNumber2.aspx (accessed 15 October 2013).

Deans, J., (2011), 'Big Fat Gypsy Weddings invites 5.6m viewers', The Guardian online version, 20 January, available at: www.guardian.co.uk/media/2011/jan/20/ratings-big-fat-gypsy-weddings (accessed 15 October 2013).

Drew, E.M., (2011), 'Pretending to be "postracial": the spectacularization of race in reality TV's Survivor', Television and New Media, 12 (4): 326-346.

Durst, J., (2011), “"What makes us Gypsies, who knows ... ?!” Ethnicity and reproduction', in Michael Stewart and Márton Rövid (eds), Multidisciplinary Approaches to Romany Studies, 13-35, Budapest: Central European University.

Engstrom, E. and Semic, B., (2003), 'Portrayal of religion in reality TV programming: hegemony and the contemporary American wedding', Journal of Media and Religion, 2 (3): 145-163.

Hall, S., (1993), 'What is this "black" in black popular culture?', Social Justice, 20 (1-2): 104-114.

Hall, S., (1996), 'New ethnicities', in David Morley and Kuan-Hsing Chen (eds), Stuart Hall Critical Dialogues in Cultural Studies, 441-449, London: Routledge.

Hall, S., (1997), "The spectacle of the "other", in Stuart Hall (ed.), Representation. Cultural Representations and Signifying Practices, 223-290, Milton Keynes: Open University Press.

Hayward, K. and Yar, M., (2006), 'The 'chav' phenomenon: consumption, media and the construction of a new underclass', Crime Media Culture, 2 (9): 9-27.

Hill, A., (2008), Reality TV: Audiences and Popular Factual Television, London: Routledge.

Humphrys, J., (2004), 'Reality TV is damaging society, says Humphrys', The Telegraph, 27 August, available at: www.telegraph.co.uk/news/1470327/Reality-TV-is-damaging-society-saysHumphrys.html (accessed 15 March 2012).

Hyland, I., (2012), 'Just a big, fat gypsy mistake', The Daily Mail, 18 February, available at: www.dailymail.co.uk/home/moslive/article-2101987/Big-Fat-Gypsy-Weddings-just-big-fat-gypsy -mistake-says-Ian-Hyland.html (accessed 13 July 2012).

Imre, A., (2005), 'Whiteness in post-Socialist Eastern Europe: the time of the Gypsies, the end of race', in Alfred Lopez (ed.), Postcolonial Whiteness: A Critical Reader on Race and Empire, 53-78, New York: State University of New York Press.

Imre, A., (2008), 'Roma music and transnational homelessness', Third Text, 22 (3): 325-336.

Imre, A., (2009), Identity Games: Globalization and the Transformation of Media Cultures in the New Europe, Cambridge, MA: MIT Press.

Imre, A., (2011), 'Love to hate: national celebrity and racial intimacy on reality TV in the New Europe', Television and New Media, 20 (10): 1-28.

Imre, A. and Tremlett, A., (2011), 'Reality TV without class: the post-Socialist anti-celebrity docusoap', in Helen Wood and Beverley Skeggs (eds), Reality Television and Class, 88-103, London: Palgrave Macmillan.

The Independent, (2012), 'Channel 4 apologises over Big Fat Gypsy Weddings photo requests', The Independent, 16 October, available at www.independent.co.uk/news/media/tv-radio/channel-4apologises-over-big-fat-gypsy-weddings-photo-requests-8213687.html (accessed 11 January 2013).

Jensen, T. and Ringrose, J., (2013), 'Sluts that choose vs doormat gypsies: exploring affect in the postfeminist, visual moral economy of My Big Fat Gypsy Wedding', Feminist Media Studies, DOI: $10.1080 / 14680777.2012 .756820$. 
Jones, O., (2011), Chavs: The Demonization of the Working Class, London: Verso.

Kürti, L., (2008), 'Media wars: cultural dialogue and conflict in Hungarian popular broadcasting', SUSDIV paper 8, January, from the Fondazione Eni Enrico Mattei Series Index, available at: www.susdiv.org/uploadfiles/SD2008-008.pdf (accessed 15 October 2013).

Lemon, A., (2000), Between Two Fires and Romani Memory from Pushkin to Postsocialism, Durham, NC: Duke University Press.

Madine, T., (2012), Tales of the Gypsy Dressmaker, London: Harper Collins.

Martin, G., (2002), 'New Age Travellers: uproarious or uprooted?', Sociology, 36 (3): 723-735.

Mayall, D., (2004), Gypsy Identities 1500-2000: From Egipcyans and Moon-men to the Ethnic Romany, London: Routledge.

McGarry, A., (2010), Who Speaks for Roma? Political Representation of a Transnational Minority Community, London: Continuum.

McKenzie, P., (2012), 'An open letter to Channel 4', 18 February 2012, Pipopotamus blog, available at: http://pipopotamus.blogspot.co.uk/2012/02/open-letter-to-chanel-4.html (accessed 15 October 2013).

Moir, J., (2011), 'My Big Fat Gypsy Wedding claims to celebrate a unique traditional culture: pull the other one, it makes Jordan look classy!' The Mail Online, 2 February, available at: www.dailymail.co.uk/debate/article-1350903/My-Big-Fat-Gypsy-Wedding-makes-Katie-Price -look-classy.html (accessed 13 July 2012).

Mondestino, N., (2001), 'The “Gypsy question” and the Gypsy expert in Sweden', Romani Studies, 11 (1): 1-23.

Mukherjee, R., (2006), 'The ghetto fabulous aesthetic in contemporary black culture', Cultural Studies, 20 (6): 599-629.

Munk, V., (2007), “ "Play to me Gypsy!” How Roma stars' image change in Hungarian media', in Kari Kallioniemi, Kimi Kärki, Janne Mäkelä and Hannu Salmi (eds), History of Stardom Reconsidered, Turku: International Institute for Popular Culture.

Okely, J., (1996), Own or other Culture, London: Routledge.

Orenstein, P., (2011), Cinderella Ate my Daughter: Dispatches from the Front Lines of the New Girlie-Girl Culture, New York: Harper Collins.

Ouellette, L. and Hay, J., (2008), 'Makeover television, governmentality and the good citizen', Continuum: Journal of Media and Cultural Studies, 22 (4): 471-484.

Perren, A., (2004), 'A big fat indie success story? Press discourses surrounding the making and marketing of a "Hollywood" movie', Communication Faculty Publications, Paper 3, available at: http://digitalarchive.gsu.edu/communication_facpub/3 (accessed 15 October 2013).

Skeggs, B., (2004), Class, Self, Culture, London: Routledge.

Skeggs, B., (2011), 'Imagining personhood differently: person value and autonomist working-class value practices', The Sociological Review, 59 (3): 496-513.

Skeggs, B., Thumin, N. and Wood, H., (2008), "Oh goodness, I am watching reality TV": How methods make class in audience research', European Journal of Cultural Studies, 11 (1): 5-24.

Skeggs, B. and Wood, H., (2011), 'Introduction: real class', in Helen Wood and Beverley Skeggs (eds), Reality Television and Class, 1-29, London: Palgrave Macmillan.

Spivak, G., (1988), 'Can the subaltern speak?', in Carl Nelson and Lawrence Grossberg (eds), Marxism and the Interpretation of Culture, 271-313, London: Macmillan.

The Sun, (2011), 'Wedding cake ... or blancmange?' The Sun online, 21 January, available at: www.thesun.co.uk/sol/homepage/showbiz/tv/3363491/Couple-promise-to-chav-and-to-hold-inChannel-4-gypsy-wedding.html (accessed 13 July 2012).

Sutcliffe, T., (2011), 'Last night's TV', The Independent online, 19 January, available at: www.independent.co.uk/arts-entertainment/tv/reviews/last-nights-tv-big-fat-gypsy-weddings -channel-4-natural-world-special-miracle-in-the-marshes-of-iraq-bbc2-2187784.html (accessed 15 October 2013).

Theodosiou, A., (2011), 'Multiculturalism and the catachresis of otherness: settling Gypsies, unsettling Gypsy belongings’, Critique of Anthropology, 31 (2): 89-107. 
Tremlett, A., (2009), 'Bringing hybridity to heterogeneity: Roma and the question of "difference" in Romani Studies', Romani Studies, 19 (2): 147-168.

Tremlett, A., (2012a), 'Why must Roma minorities be always seen on the stage and never in the audience? Children's opinions of reality Roma TV', in Timothy Havens, Aniko Imre and Katalin Lustyik (eds), Entertaining the New Europe: Popular Television in Socialist and Postsocialist Eastern Europe, 241-258, London: Routledge.

Tremlett, A., (2012b), " "Here are the Gypsies!" The importance of self-representations and how to question prominent images of Roma minorities', Ethnic and Racial Studies, 36 (11): 17061725.

Tremlett, A., (2013), 'Roma, non-Roma and the modern working-class (familiar) stranger', in Maja Miskovic (ed.), Roma Education in Europe, London: Routledge.

Tremlett, A. and McGarry, A., (2013), 'Challenges facing researchers on Roma Minorities in contemporary Europe: notes towards a research program', European Center for Minority Rights Working Paper No. 62, January, available at: www.ecmi.de/uploads/tx_lfpubdb/ Working_Paper_62_Final.pdf (accessed 15 October 2013).

Turner, G., (2004), Understanding Celebrity, London: Sage.

Turner, G., (2006), "The mass production of celebrity: "celetoids", reality TV and the "demotic turn" , International Journal of Cultural Studies, 9 (2): 153-165.

Turner, G., (2010), Ordinary People and the Media: The Demotic Turn, London: Sage.

Tyler, I. and Bennett, B., (2010), 'Celebrity chav: fame, femininity and social class', European Journal of Cultural Studies, 13 (3): 375-393.

Van Dijk, T., (2000), 'New(s) racism: a discourse analytical approach', in Simon Cottle (ed.), Ethnic Minorities and the Media, 33-49, Buckingham: Open University Press.

Willems, W., (1997), In Search of the True Gypsy, London: Frank Cass.

Helen Woods and Bevereley Skeggs (eds), (2011), Reality Television and Class, London: Palgrave Macmillan. 